\title{
Autoimmune Hepatitis Variant: Overlap Syndrome with Primary Biliary Cholangitis
}

\author{
Ugur Ergun (Corresponding author) \\ Balikesir Universiy Faculty of Medicine, Department of Internal Medicine, Balikesir, Turkey \\ E-mail: mdbalkes10@gmail.com \\ Berkay Kuscu \\ Balikesir Universiy Faculty of Medicine, Department of Internal Medicine, Balikesir, Turkey \\ Merve Nur Ak \\ Balikesir Universiy Faculty of Medicine, Department of Internal Medicine, Balikesir, Turkey
}

Omer Faruk Turan

Balikesir Universiy Faculty of Medicine, Department of Internal Medicine, Balikesir, Turkey

Elif Nur Avsar

Balikesir Universiy Faculty of Medicine, Department of Internal Medicine, Balikesir, Turkey

Burak Alp

Balikesir Universiy Faculty of Medicine, Department of Internal Medicine, Balikesir, Turkey

Ahmet Urk

Balikesir Universiy Faculty of Medicine, Department of Internal Medicine, Balikesir, Turkey

Burcu Ozkan

Balikesir Universiy Faculty of Medicine, Department of Internal Medicine, Balikesir, Turkey

Erkan Caglar

Balikesir Universiy Faculty of Medicine, Department of Gastroenterology, Balikesir, Turkey

\begin{abstract}
Autoimmune hepatitis is a liver parenchymal disease that causes necroinflammatory chronic hepatitis, which is the more common cause of inflammation in women. Serum is characterized by autoantibodies and immunoglobulin height. Primary biliary cholangitis is a chronic cholestatic liver disease characterized by the destruction of intralobular bile duct damage and mostly middle-aged women with the effects of genetic and environmental factors. These two diseases can cause cirrhosis of the liver. In the literature, cirrhotic cases of liver cirrhosis caused by autoimmune hepatitis and primary biliary cholangitis have been reported. In this rare case, which is defined as overlap syndrome, early diagnosis and treatment are important. We present a case of autoimmune hepatitis and primary biliary cholangitis due to overlap syndrome in the etiology of decompensated liver cirrhosis.
\end{abstract}

Keywords: Liver Cirrhosis, Autoimmune Hepatitis, Primary Biliary Kolangitis

DOI: $10.7176 / \mathrm{JSTR} / 5-6-07$

\section{Giriş}

Otoimmün hepatit (OİH) karaciğerde kronik hepatite yol açtığı bilinen bir etiyolojik ajanın yokluğunda, nedeni bilinmeyen inflamasyonla seyreden, histolojik olarak interface hepatit, serum otoantikorlar1 ve hipergamaglobulinemi ile karakterize ilerleyici, kronik, nekroinflamatuar bir karaciğer parankim hastalığıdır $(1,2)$ 
Yeni terminolojik adlandırma ile primer biliyer kolanjit (PBK) kronik otoimmün bir karaciğer hastalığıdır. Hastalı̆̆ın patogenizi tam olarak aydılantılmamıştır. Kaşıntı ve yorgunluk semptomları çok sık olmakta olup sarılık, kolestatik enzim yüksekliği ve sirozunsemptom ve işaretlerini içerebilmektedir (3).

OİH'li bir hasta, anti-mitokondiral antikor pozitifliği yanında PBK'nın özelliklerinede sahip ise bu birliktelik overlap sendromu olarak değerlendirilmektedi (4). Dekompanse karaciğer sirozlu olgumuzun etiyolojisine yönelik incelemesinde $\mathrm{OIH}+\mathrm{PBK}$ overlap düşünüldü. Böylece nadir görülen bu olgu sunumuzu sunmak istedik.

\section{Olgu Sunumu}

64 yaşında kadın hasta karında şişlik şikayetiyle gastroenteroloji polikliniğimize başvurdu. Anamnezinde bu şikayetinin yaklaşık 3 aydır mevcut olduğu öğrenildi. Öz geçmişi ile soy geçmişinde belirgin bir özellik yoktu. Hastanın sürekli kullanmakta olduğu ilaç bulunmamaktaydı. Bitki kullanımı ile alkol tüketimi olmayan hastanın ateşi $36.6^{\circ} \mathrm{C}$, nabzı $59 /$ dakika ve kan basınc $110 / 70 \mathrm{mmHg}$ olan olup fizik muayenesinde batın distandü görünüm ile traube kapalı dışında patolojik bulgu tespit edilmedi. Laboratuvar sonuçlarında hemoglobin düzeyi $10.1 \mathrm{~g} / \mathrm{dL}(13.5-17.5 \mathrm{~g} / \mathrm{dL})$, lökosit sayısı 4.000/ $\mathrm{mm}^{3}$ $\left(4.000-10.000 / \mathrm{mm}^{3}\right)$, trombosit say1s1 $70.000 / \mathrm{mm}^{3}\left(150.000-400.000 / \mathrm{mm}^{3}\right)$, aspartat aminotransferaz (AST): $51 \mathrm{IU} / \mathrm{L}$ (15-41 IU/L), alanin aminotransferaz (ALT): $21 \mathrm{IU} / \mathrm{L}$ (14-54 IU/L), gamaglutamil transferaz (GGT): $71 \mathrm{IU} / \mathrm{L}$ (7-50 IU/L), alkalen fosfataz (ALP): $283 \mathrm{IU} / \mathrm{L}$ (50-120 IU/L), total bilirubin $1.81 \mathrm{mg} / \mathrm{dL}(0.4-1.4 \mathrm{mg} / \mathrm{dL})$, direkt bilirubin $0.56 \mathrm{mg} / \mathrm{dL}(0.1-0.5 \mathrm{mg} / \mathrm{dL})$, albümin $3.4 \mathrm{~g} / \mathrm{dL}(3.5-5.2$ $\mathrm{g} / \mathrm{dL}$ ), total protein $9.1 \mathrm{~g} / \mathrm{dL}(6.6-8.3 \mathrm{~g} / \mathrm{dL})$, üre: $39 \mathrm{mg} / \mathrm{dL}$, kreatinin: $0.76 \mathrm{mg} / \mathrm{dL}$, sodyum $(\mathrm{Na}): 134$ $\mathrm{mmol} / \mathrm{L}$, potasyum (K):5.0, protrombin zamanı (INR): 3.08 (1-1.5 INR), aktive parsiyel tromboplastin zamanı (aPTT): $32.5 \mathrm{sn}(26.5-40 \mathrm{sn})$, eritrosit sedimentasyon hızı (ESH): $38 \mathrm{~mm} / \mathrm{saat}(0-20 \mathrm{~mm} / \mathrm{saat})$, creaktif protein (CRP) $110 \mathrm{mg} / \mathrm{L}$ ( normal $<3.5 \mathrm{mg} / \mathrm{L}$ ) dışında patolojik bulgu yoktu. Tüm abdomen ultrasonografi (US)'de karaciğer parankimi heterojen eko yapısında olup konturları lobüle, dalak boyutu $16.4 \mathrm{~cm}$ çapında splenomegali ile batın içinde assit izlendiği görülmüştür. US'da batında assit saptanan hasta dekompanse karaciğer siroz olarak kabul edildi. Hastanın Child Pugh sınıflamasına göre skoru 10 ve grubu C idi. MELD skoru 20 olarak hesaplanan hastanın portal ven renkli doppler US'de tromboz lehine bulgu saptanmamış olup portal hipertansiyon ile uyumlu bulunmuştur. Portal hipertansiyon açısından özefagogastroskoduodenoskopi ile değerlendirilen hastada varis saptanmadı. Diagnostik parasentez yapılan hastanın assit sıvısı transuda niteliğinde olup serum asit albümin gradienti $1.8 \mathrm{~g} / \mathrm{dL}$ bulundu. Kardiyak patolojisi olmayan hastaya terapötik parasentez işlemi yapıldı. Sprinolakton $100 \mathrm{mg}$ ile furosemid $40 \mathrm{mg}$ şeklinde tedavisi başlandı. Hepatoksik ilaç öyküsü olmayan hastanın viral hepatit serolojisi negatif olup, Epstein Barr virüs, Sitomegalovirüs ve Herpes virüs markırları negatif olarak belirlendi. Etiyolojiye yönelik immünglobulin düzeyleri ile otoimmun markıları istendi. Hastanın IgG 44.6 g/L (8-17 g/L), IgM 4.08 g/L (0.9-1.18 g/dL), anti-nükleer antikor (ANA): 1/100 pozitif, antimitokondrial antikor (AMA): 1/320 pozitif, AMA-M2 pozitif, karaciğer/böbrek mikrozomal otoantikoru1 (LKM-1) negatif, anti-düz kas antikoru (ASMA) negatif ile idrarda bakılan bakır düzeyi normal olarak bulundu.

Fizik muayene ve laboratuvar tetkik sonuçlarıyla değerlendirildiğinde hastanın dekompanse karaciğer siroz tablosu nadir görülen OİH+PBK overlap sendromuna bağlı olduğu tespit edildi. Hastaya karaciğer biyopsisi yapılması istenildi ancak INR değeri yüksekliği ile trombositopenisi olması nedeniyle karaciğer biyopsisi yapılamadı. Hastaya düşük doz kortikosteroid ile ursodeoksikolikasit tedavisi başlandı. Poliklinik kontrollerinde karaciğer fonksiyon testlerinde düzelme izlendi.

\section{Tartışma}

OİH, kronik karaciğer bir hastalık olup seyri sırasında siroz, karaciğer yetmezliği ve hatta ölüme neden olabilecek önemli bir hastalıktır. Temel patogenez organizmanın kendi karaciğer dokusuna karşı toleransının kaybolması ile ilgilidir. OİH'li hastalar başvuru sırasında bir çok farklı klinik ile ortaya çıkabildiği gibi karaciğer sirozu ile görülebilmektedir $(5,6)$. Olgumuzda dekompanse karaciğer siroz tablosu mevcuttu.

Laboratuvar tetkikleri gerek OİH tanısının konulmasında, gerekse bu tabloya neden olabilecek viral hepatit, toksik hepatit, Wilson hastalığı, alfa-1 antitripsin eksikliği gibi genetik geçişli karaciğer hastalıkları, PBK gibi hastalıkların dışlanmasında yardımcıdır $(5,6)$. Otoantikorların ve hipergamaglobulinemin varlığı, OİH tanısını destekleyen en önemli parametrelerdir. Kadınlarda sık görülen OİH immünserolojik göstergelere göre üç tipe ayrılmaktadır. En sık görülen formu, olguların \% 85'i oluşturan ve özellikle ANA ve/veya ASMA pozitifliği ile giden tip 1 OİH formudur (7). Olgumuzda immünglobin G yüksekliği ile ANA yüksekliği tip 1 OİH ile uyumlu olarak değerlendirildi.

Literatürde OİH ile diğer otoimmün karaciğer hastalıkları ile birlikte görüldüğü bildirilmiştir. OİH’li

53 | $P$ a g e

www.iiste.org 
hastalarda kolestaz enzimlerinde yükseklik, otoantikorlardan AMA pozitifliği varlığında OİH ve PBK overlap sendromu varlığı düşünülmelidir (7). Olgumuzdaki AMA pozitifliği, immünglobin M yüksekliği ile beraber ALP, GGT yükseliği olması PBK tanısı güçlendirdi.

$\mathrm{Bu}$ hastalardan tanıyı destelemek amacıyla herhangi bir kontrendikasyon yoksa karaciğer biyopsisi yapılması önerilir. Karaciğer biyopsisinde OİH için spesifik olmamak ile birlikte, karakteristik değişiklikler görülür (7). Olgumuzda INR yüksekliği ile trombosit sayısının düşük olması kanama riskini yüksek oranda artırmaktaydı. Bu yüzden histopatolojik tanı için karaciğer biyopsisi yapılamadı.

Sonuç olarak, OİH'li hastalarda ek kolestaz enzim yüksekliği ile AMA özellikle M2 paterni yüksek otoantikorlar varlığında PBK'nın eşlik edebileceği düşünülmelidir. OİH+PBK overlap sendromu olarak tanımlanan bu tabloda multidisipliner tedavi ön planda tutulmalıdır. Böylece erken tanı ve tedavi ile ortaya çıkabilecek komplikasyonların kontrol edilmesine yardımcı olacağını düşünmekteyiz.

\section{Kaynaklar}

[1] Edward L. Krawitt, M.D., Autoimmune hepatitis. N.Engl. J. Med. 2006;354:54-66.

[2] Czaja AJ., Emerging drug therapies and site spesific interventions for autoimmune hepatitis Medicinal Chemistry Reviews online 2004, 1, 445-55

[3] Dursun H. Primer Biliyer Kolanjit. Demir M, editör. Kolestatik Karaciğer Hastalıkları. Ankara: Türkiye Klinikleri; 2018. p.25-8.

[4] Ben-Ari Z, Czaja AJ., Autoimmune hepatitis and its variant syndromes. Gut 2001;49:589-94.

[5] Teufel A, Gale PR, Kanzler S. Update on autoimmune hepatitis. World J Gastroenterol 2009;15:1035-41.

[6] Krawitt EL. Autoimmune hepatitis. N Engl J Med 2006;354:54-66.

[7] Cerit ET, Yurdaydın C. Otoimmun hepatit ve varyantları. Güncel Gastroenteroloji 2006;10:24656. 